\title{
Accelerating Effect of Natural Unsaturated Fatty Acids on Photodecomposition of Chinomethionat (Morestan ${ }^{\circledR}$ )
}

\author{
Masakatsu Nutahara and Toshinobu Murai* \\ The Kochi Prefectural Institute of Agricultural and Forest Science, Ino, Kochi 781-21, Japan \\ *National Institute of Agro-Environmental Sciences, Yatabe-machi, \\ Tsukuba-gun, Ibaraki 305, Japan
}

(Received April 3, 1984)

\begin{abstract}
Photodecomposition of chinomethionat (S,S-6-methylquinoxaline-2,3-diyl dithiocarbonate, Morestan $($ ) was remarkably accelerated by natural unsaturated fatty acids such as oleic acid. The accelerating effect was based on the unsaturated double bond. In the homologous series of unsaturated fatty acids, increase in number of double bonds resulted in more enhanced photodecomposition of chinomethionat. Accelerating activity of normal chain unsaturated fatty acids with a double bond increased with the decrease in the length of carbon chain and with the increase of carbon chains between the double bond and carboxyl group. Among the structural isomers of unsaturated fatty acids, cis-forms showed much higher accelerating activity in comparison with trans-forms. The photodecomposition of chinomethionat was also accelerated by non-ionic surfactants and fatty oils containing unsaturated fatty acid moiety. Chinomethionat was almost completely decomposed by irradiation with UV light for $24 \mathrm{hr}$ when oleic acid was added over 23 times in molar ratio. The photodecomposition of anilazine, chlomethoxynil, chlornitrofen, chlorothalonil, dichlozoline, dicofol and procymidone was also accelerated in the presence of oleic acid, among other 26 pesticides tested.
\end{abstract}

\section{INTRODUCTION}

In an investigation of the photodecomposition of chinomethionat $(S, S-6$-methylquinoxaline-2,3-diyl dithiocarbonate, Morestan $\left.{ }^{\circledR}\right)$, it was found that the photodecomposition was remarkably accelerated by extract from vegetable leaves. ${ }^{1)}$

Previous investigations in relation to accelerators of pesticide photodecomposition have mostly been concerned with well-known photosensitizers with high triplet-energy values $^{2,3)}$ and surfactants. ${ }^{4,5}$ There has been little information as to natural substances which accelerate photodecomposition of pesticides, except for chlorophyll and other few compounds. ${ }^{6,7)}$ If chemicals for controlling pesticide photodecomposition are developed, it may be possible to regulate the persistence of pesticides in the environment. For this purpose, natural substances are of greater advantage, from the viewpoint of environmental toxicology. In the present paper, photodecomposition accelerators of chinomethionat in eggplant leaves were identified and their characteristics were investigated.

\section{MATERIALS AND METHODS}

\section{Chemicals}

Standard substances of anilazine [2,4-dichloro-6-(2-chloroanilino)-1,3,5-triazine], captafol $[N-(1,1,2,2$-tetrachloroethylthio)cyclohex4-ene-1,2-dicarboximide], chinomethionat, chlorobenzilate (ethyl 4,4'-dichlorobenzilate), chlorothalonil (tetrachloroisophthalonitrile), $o$, $p^{\prime}$-DDT [1,1,1-trichloro-2-(2-chlorophenyl)-2(4-chlorophenyl)ethane], $p, p^{\prime}$-DDT $[1,1,1$-trichloro-2,2-bis (4-chlorophenyl) ethane], dicofol [2,2,2-trichloro-1,1-bis(4-chlorophenyl)ethanol], dichlofluanid ( $N$-dichlorofluoromethylthio- $N^{\prime}$, 
$N^{\prime}$-dimethyl- $N$-phenylsulfamide $)$, dieldrin [(1R, $4 S, 5 S, 8 R$ ) -1 ,2,3,4,10,10-hexachloro- $1,4 \mathrm{a}, 5,6,7$, 8,8a-octahydro-6,7-epoxy-1,4:5,8-dimethanonaphthalene], proclonol [bis(4-chlorophenyl)cyclopropylmethanol], and simazine [2-chloro4,6-di (ethylamino)-1,3,5-triazine] were purchased from Wakō Pure Chemical Industries Ltd., Tokyo, Japan.

Chlorfenethol [1,1-bis (4-chlorophenyl)ethanol], dichlozoline [3-(3,5-dichlorophenyl)-5,5dimethyloxazolidine-2,4-dione], diuron [3-(3,4dichlorophenyl)-1,1-dimethylurea], tetrachlorophthalide $(4,5,6,7$-tetrachlorophthalide), iprodione [3-(3,5-dichlorophenyl)- $N$-isopropyl-2,4dioxoimidazolidine-1-carboxamide], procymidone $[N$-(3,5 - dichlorophenyl) -1,2 - dimethylcyclopropane-1,2-dicarboximide], vinclozolin[3(3,5-dichlorophenyl) -5-methyl-5-vinyloxazolidine 2,4-dione], chlomethoxynil(2,4-dichlorophenyl 3-methoxy-4-nitrophenyl ether) and chlornitrofen (2, 4, 6 - trichlorophenyl 4-nitrophenyl ether) were extracted with acetone from wettable powders or granular formulations which were commercially available.

The following pesticides were employed as emulsifiable concentrates: dialifor [S-(2-chloro1-phthalimidoethyl) $O, O$-diethyl phosphorodithioate], isoprothiolane (diisopropyl 1,3-dithiolane-2-ylidenemalonate), bromopropylate (isopropyl 4,4'-dibromobenzylate), propaphos [4-(methylthio) phenyl dipropyl phosphate], propargite [2-(4-tert-butylphenoxy)cyclohexylprop-2-ynyl sulphite], and tetradifon (4-chlorophenyl 2,4,5-trichlorophenyl sulfone).

All other reagents, which were of analytical grade, were purchased from Wakō Pure Chemical Ind., Ltd. and Nakarai Chemicals Ltd., Japan.

\section{Plant Materials}

Eggplant (c.v., Kairyo-Soshin), cucumber (c.v., Ogon-Sokusei) and greenpepper (c.v., Shin-Sakigake-Midori) were cultivated in a greenhouse. The residues of pesticides in treated vegetables were examined from February 5 th to 12 th, in 1980 . Temperatures in the greenhouse changed between 15 and $30^{\circ} \mathrm{C}$, during the period of the experiment.

\section{Gas Liquid Chromatography (GLC)}

The GLC for fatty acids was carried out with Shimadzu model 3B gas chromatograph equipped with flame ionization detector (FID) under the following conditions. A GLC pyrex glass column $(170 \mathrm{~cm} \times 3 \mathrm{~mm}$ i.d. $)$ was packed with $2 \%$ DEGS-0.5\% phosphoric acid on Gaschrom Q (80-100 mesh). Column temperature was either 200 or $160^{\circ} \mathrm{C}$. Temperatures of injection port and detector were 220 and $210^{\circ} \mathrm{C}$, respectively. The flow rates of nitrogen (carrier gas), air and hydrogen were $80 \mathrm{ml} / \mathrm{min}$, $55 \mathrm{ml} / \mathrm{min}$, and $40 \mathrm{ml} / \mathrm{min}$, respectively.

The GLC for pesticides was carried out with Shimadzu model 3B and model 5A equipped with flame photometric detector (FPD) and electron capture detector (ECD). GLC columns were pyrex glass $(170 \mathrm{~cm} \times 3 \mathrm{~mm}$ i.d. packed with $3 \%$ Silicone GE SE-30 on Chromosorb W (AW-HMDS, 80-100 mesh), 2\% DEGS$0.5 \%$ phosphoric acid on Gas-chrom Q (80$100 \mathrm{mesh}$ ) and $2 \%$ Silicone OV-17 on Gaschrom Q (80-100 mesh). Column temperature varied in the range of 160 to $240^{\circ} \mathrm{C}$ to suit the particular compound. Temperatures of the injection port and the detector were always maintained above column temperatures. The flow rates of nitrogen, air, and hydrogen in analysis with model $3 \mathrm{~B}$ were $80 \mathrm{ml} / \mathrm{min}, 30$ $\mathrm{ml} / \mathrm{min}$ and $40 \mathrm{ml} / \mathrm{min}$, respectively. The flow rate of nitrogen in model $5 \mathrm{~A}$ was $120 \mathrm{ml} / \mathrm{min}$.

\section{Exposure to UV light and Sunlight}

Ten $\mu \mathrm{g}$ residual deposits of chinomethionat were prepared by spreading acetone solution uniformly over the surface of a petri dish $(5 \mathrm{~cm}$ in diameter). The treated dishes were exposed to UV light, emitted from fluorescent blacklight lamps (FL-15-BLB, $\times 4)$, at a distance of $16 \mathrm{~cm}$, for given periods, at $20^{\circ} \mathrm{C}$.

After exposure, residual chinomethionat on the petri dish was rinsed with acetone and then subjected to GLC analysis. Other pesticides were also irradiated in the same manner as described above. Exposure to sunlight was conducted for $4 \mathrm{hr}$ under fine weather conditions.

\section{Measurement of Accelerating Activity}

Accelerated photodecomposition of pesticides was measured on the surface of the petri dish in the presence of various compounds. The amounts of test compounds added to $10 \mu \mathrm{g}$ of 


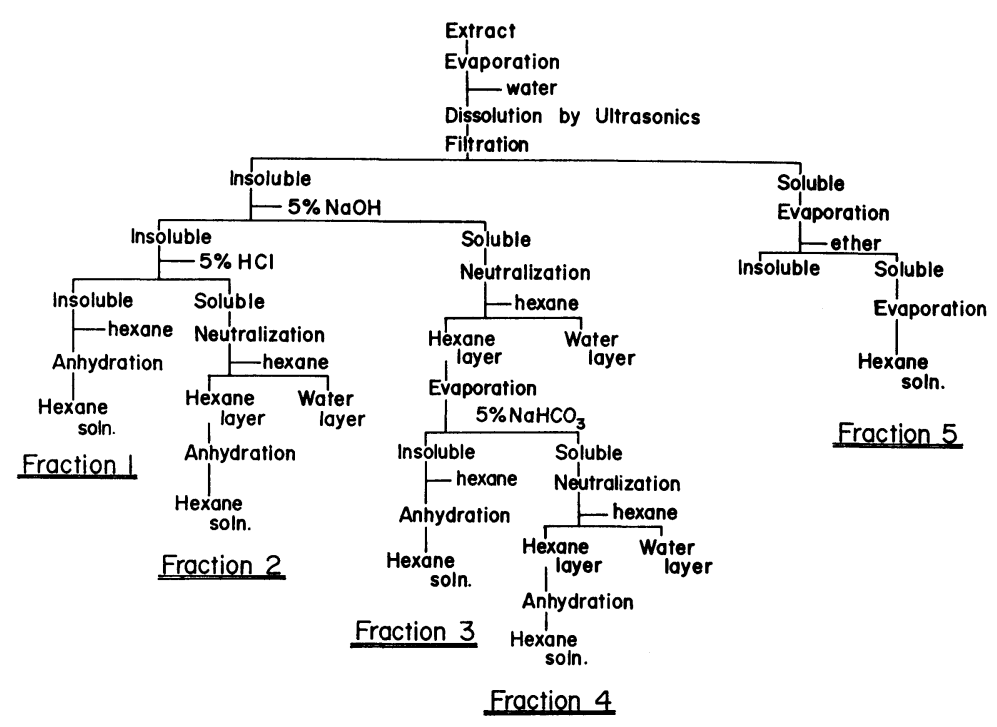

Fig. 1 Fractionation procedure of extract with $n$-hexane from eggplant leaves.

a pesticide were $0.5 \mu \mathrm{mol}$ for fatty acids and $200 \mu \mathrm{g}$ for fatty oils and surfactants. After mixed deposits on petri dishes were exposed to UV light or sunlight, the residual amounts of pesticides were determined by GLC. The accelerating activity on photodecomposition of pesticides was evaluated on the basis of the decomposition rate.

\section{Separation and Identification of Photodecom- position Accelerators in Vegetable Leaves}

Leaves of eggplant, cucumber, and greenpepper were dipped in $n$-hexane for 2 days with occasional shakings. The extract was thoroughly dried over anhydrous sodium sulfate, and concentrated to a small volume under reduced pressure at $40^{\circ} \mathrm{C}$. The concentrated extracts were methylated according to the method described by Murai et al., ${ }^{8)}$ and subjected to GLC.

A part of the concentrated extract from eggplant was fractionated by the procedure shown in Fig. 1, and accelerating activity of each fraction was evaluated by the same method as described above. The accelerating substance in each fraction was identified by the comparison of retention times with possible reference compounds by GLC.
7. Accelerated Photodecomposition of Chinomethionat on Vegetable Crops by Oleic Acid

Spray solutions of chinomethionat were prepared from a wettable powder (a.i. 25\%) at 2000 times dilution. Oleic acid and Tween 60 (as a dispersing agent) were added at the concentration of $0.2 \%$ and $0.04 \%$, respectively. Application of each spray onto the vegetables was conducted at the spray rate of $280 l / 10 \mathrm{a}$.

\section{RESULTS AND DISCUSSION}

\section{Identification of Photodecomposition Accel- evators in Vegetable Leaves}

The extract from eggplant leaves was fractionated and then accelerating activity on photodecomposition of chinomethionat of each fraction was examined. As shown in Table 1, the maximum activity was found in fraction 4 , followed by fraction 5 , while the others were scarcely effective. This suggested that the accelerator was regarded as an acidic compound.

Figure 2 shows the results of GLC conducted with the methylated product of each fraction. A certain characteristic peak (designated by an arrow in Fig. 2) was observed on the gas chromatogram. The area of the peak was closely correlated with the accelerating activity of each fraction. Furthermore, this peak disappeared after exposure to UV light in the presence of chinomethionat (Fig. 3). From the 
Table 1 Accelerating activity of each fraction of eggplant leaf-extract on photodecomposition of chinomethionat exposed to UV light on petri dish.

\begin{tabular}{ccc}
\hline & \multicolumn{2}{c}{ Decomposed (\%) } \\
\cline { 2 - 3 } Fraction No. & $\begin{array}{c}30 \mathrm{~min}, \\
\text { Exposed }\end{array}$ & $\begin{array}{c}60 \mathrm{~min}, \\
\text { Exposed }\end{array}$ \\
\hline 1 & 15 & 14 \\
2 & 0 & 8 \\
3 & 0 & 6 \\
4 & 53 & 67 \\
5 & 28 & 53 \\
\hline
\end{tabular}

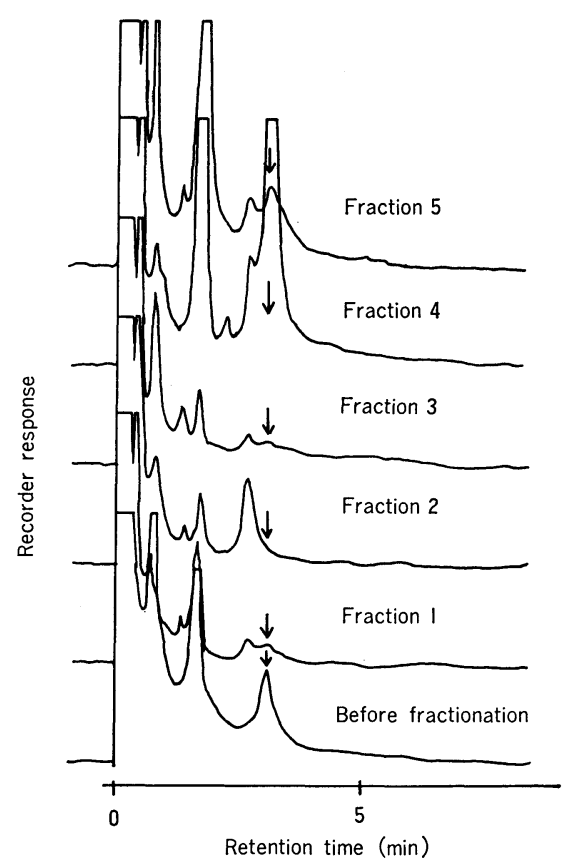

Fig. 2 Gas chromatograms of each fraction of eggplant leaf-extract after methylation.

$\downarrow$ : peak corresponding to methyl oleate (see text).

above results, the reasonable conclusion was that the compound of the peak was the methyl compound of an accelerator and that the accelerator was consumed in accelerated photodecomposition of chinomethionat. The compound corresponding to the peak, was identified as methyl oleate by comparison with the authentic compound by GLC.

The mixtures of chinomethionat $(10 \mu \mathrm{g}=$

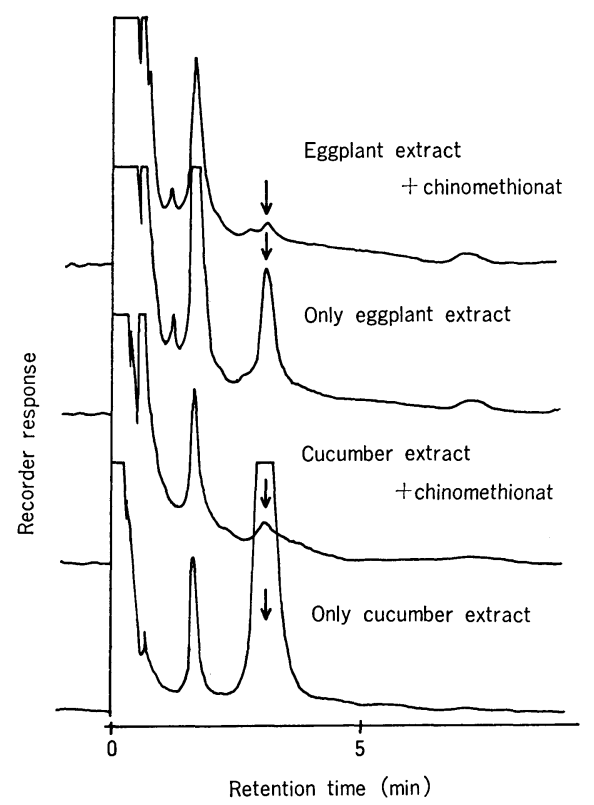

Fig. 3 Gas chromatograms of methylated extract of eggplant leaves and cucumber leaves after exposure to UV light.

$\downarrow$ : peak corresponding to methyl oleate (see text).

$\left.4.27 \times 10^{-2} \mu \mathrm{mol}\right)$ and oleic acid $\left(5.00 \times 10^{-1}\right.$ $\mu \mathrm{mol}$ ) were exposed to UV light or to sunlight on the petri dish. As shown in Fig. 4, the photodecomposition of chinomethionat under UV light or under sunlight was remarkably accelerated in the presence of oleic acid, respectively. This suggested that the main accelerator in vegetable leaves was oleic acid.

\section{Accelerating Activity of Fatty Acids}

Accelerating activity of several saturated and unsaturated fatty acids, which probably exist in vegetable leaves, was also examined. As shown in Table 2, the photodecomposition of chinomethionat was enhanced only by unsaturated fatty acids, namely, oleic acid and linoleic acid, and the photodecomposition was scarecely accelerated by saturated ones. The result suggested that the presence of unsaturated bond (double bond) was indispensable for the accelerating effect.

Table 3 shows the comparison of the accelerating activity among unsaturated fatty acids. Increase in number of double bonds 


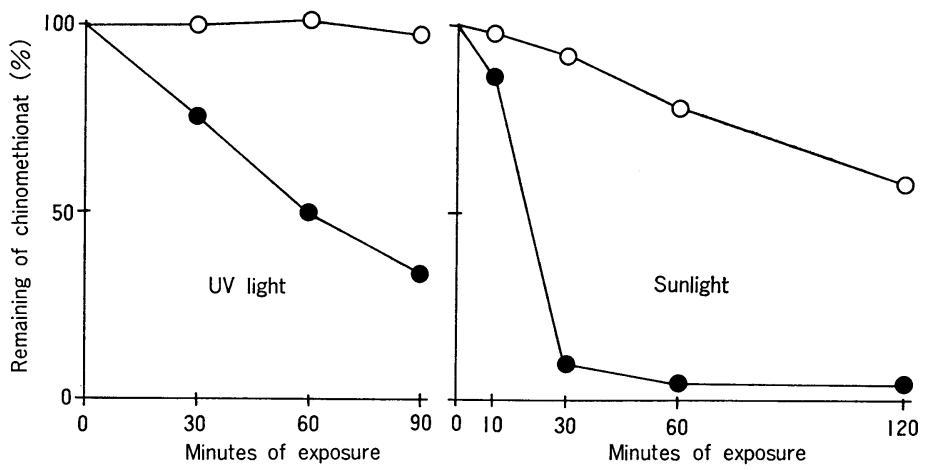

Fig. 4 Accelerating activity of oleic acid on photodecomposition of chinomethionat exposed to UV light or to sunlight on petri dish.

○: without oleic acid, $\bullet$ : with oleic acid.

Table 2 Accelerating activity of fatty acids on photodecomposition of chinomethionat exposed to UV light on petri dish.

\begin{tabular}{lccc}
\hline \multirow{2}{*}{ Fatty acid } & $\begin{array}{c}\text { Number of } \\
\text { unsaturated } \\
\text { bond }\end{array}$ & \multicolumn{2}{c}{ Decomposed (\%) } \\
\cline { 3 - 4 } & - & 0 & 0 \\
$2 \mathrm{hr}$, & $2 \mathrm{hr}$, \\
Dark & Exposed \\
\hline Control & 0 & 9 & 0 \\
Lauric acid & 0 & 0 & 0 \\
Miristic acid & 0 & 0 & 5 \\
Palmitic acid & 0 & 0 & 0 \\
Stearic acid & 1 & 4 & 89 \\
Oleic acid & 2 & 0 & 60 \\
Linoleic acid & 0 & & \\
\hline
\end{tabular}

resulted in more accelerated photodecomposition of chinomethionat. There was a distinct difference between structural isomers. In general, the activity of trans-forms was lower than that of their cis-isomers. In particular, the activity of elaidic acid which was transisomer of oleic acid was quite negligible.

In the series of myristoleic acid (tetradecenoic acid), oleic acid (octadecenoic acid) and nervonic acid (tetracosenoic acid) containing a double bond in cis-configuration, the accelerating activity decreased with the increasing length of carbon chain. In addition, the accelerating activity increased with increasing carbon chains between double bond and carboxyl group, judging from the results with petroselinic acid, oleic acid and vaccenic acid, which are octadecenoic acids containing a double bond.

Table 3 Accelerating activity of unsaturated fatty acids on photodecomposition of chinomethionat exposed to UV light on petri dish.

\begin{tabular}{lccc}
\hline Fatty acid & $\begin{array}{c}\text { Number } \\
\text { of carbon }\end{array}$ & $\begin{array}{c}\text { Position of } \\
\text { double bond }\end{array}$ & $\begin{array}{c}\text { Decomposed (\%) } \\
\text { hr, Exposed }\end{array}$ \\
\hline Control & - & - & 0 \\
Myristoleic acid & 14 & cis-9 & 58 \\
Petroselinic acid & 18 & cis-5 & 45 \\
Oleic acid & 18 & cis-9 & 52 \\
Elaidic acid & 18 & trans-9 & 0 \\
Vaccenic acid & 18 & cis-11 & 64 \\
trans-Vaccenic acid & 18 & cis-9, 12 & 28 \\
Linoleic acid & 18 & cis-9, 12, 15 & 55 \\
Linolenic acid & 18 & cis-15 & 68 \\
Nervonic acid & 24 & & 45 \\
\hline
\end{tabular}


3. Accelerating Activity of Other Unsaturated Compounds

Numbers of unsaturated compounds were examined, in order to confirm the structural requirements for accelerating activity. Table 4 shows the activity of fatty oils containing unsaturated fatty acid moiety. All of fatty oils tested were apparently effective in the photodecomposition of chinomethionant.

The activity of non-ionic surfactants containing unsaturated fatty acid moiety, which have been used for a spreader of pesticides, was examined. The activity of Tween 85 (polyoxyethylene sorbitan trioleate) was the greatest, followed by Tween 80 (polyoxyethylene sorbitan monooleate) and Tween 60 (polyoxyethylene sorbitan monolaurate) (Fig. 5). These results showed conclusively that the

Table 4 Accelerating activity of fatty oils on photodecomposition of chinomethionat exposed to UV light on petri dish.

\begin{tabular}{lc}
\hline \multicolumn{1}{c}{ Fatty oil } & Decomposed (\%) \\
\hline Control & 9 \\
Castor oil & 95 \\
Linseed oil & 91 \\
Olive oil & 98 \\
Soy bean oil & 97 \\
\hline
\end{tabular}

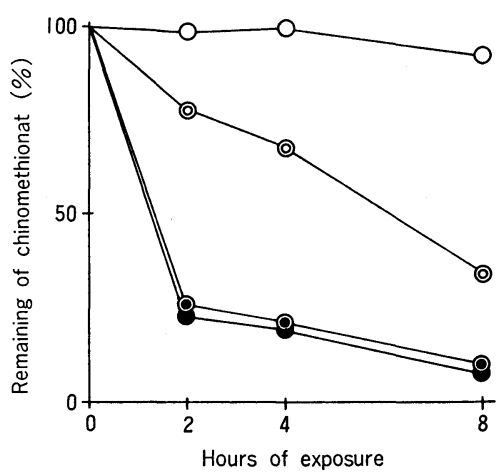

Fig. 5 Accelerating activity of surfactants on photodecomposition of chinomethionat exposed to UV light on petri dish.

$\bigcirc$ : without surfactant, ๑: Tween 60 (Polyoxyethylene Sorbitan Monolaurate), ๑: Tween 80 (Polyoxyethylene Sorbitan Monooleate),

Tween 85 (Polyoxyethylene Sorbitan Trioleate). accelerating effect was attributtable to the unsaturated double bond of these compounds tested.

\section{Characterization of Accelerating Activity of Oleic Acid}

The photodecomposition rate of chinomethionat increased with the increasing quantity of oleic acid. Chinomethionat was almost completely decomposed by irradiation with UV light for $24 \mathrm{hr}$ when the quantity of oleic acid reached about 23 times that of chinomethionat in molar ratio (Fig. 6). Another experiment indicated that oleic acid was stable to UV light. However, the addition of chinomethionat, during UV irradiation, resulted in a remarkable decrease of oleic acid. After

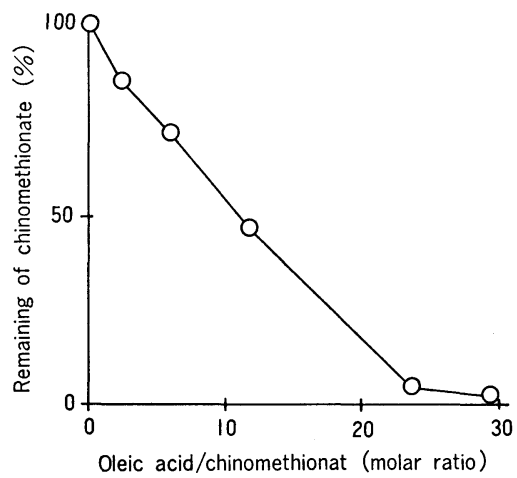

Fig. 6 Relationship between quantity of oleic acid and photodecomposition rate of chinomethionat exposed to UV light for 2 hours on petri dish.

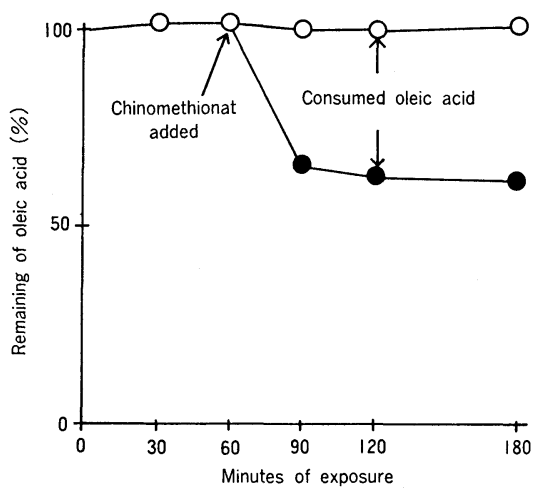

Fig. 7 Consumption of oleic acid in photodecomposition reaction of chinomethionat exposed to UV light on petri dish. 
Table 5 Accelerating activity of oleic acid on photodecomposition of pesticides exposed to UV light on petri dish.

\begin{tabular}{|c|c|c|c|c|c|c|c|}
\hline \multirow{2}{*}{ Pesticide } & \multicolumn{2}{|c|}{ Decomposed (\%) } & \multirow{2}{*}{ Pesticide } & \multicolumn{4}{|c|}{ Decomposed (\%) } \\
\hline & $4 \mathrm{hr}$ & $16 \mathrm{hr}^{\mathrm{a})}$ & & $4 \mathrm{hr}$ & $16 \mathrm{hr}$ & $64 \mathrm{hr}$ & $72 h^{a)}$ \\
\hline Chinomethionat & & $95(14)$ & Anilazine & & $41(24)$ & $89(47)$ & \\
\hline Chlorfenethol & & $2(0)$ & Captafol & & $31(31)$ & & \\
\hline Chlorobenzilate & & $0(24)$ & Chlorothalonil & & $32(11)$ & & $87(37)$ \\
\hline$o, p^{\prime}-\mathrm{DDT}$ & & $0(43)$ & Dichlofluanid & $2(13)$ & $43(29)$ & & \\
\hline$p, p^{\prime}-\mathrm{DDT}$ & & $0(44)$ & Dichlozoline & & $23(7)$ & $79(39)$ & \\
\hline Dialifor & & $0(13)$ & Tetrachlorophthalide & & $6(2)$ & & \\
\hline Dicofol & $80(2)$ & $98(25)$ & Iprodione & & & $1(4)$ & \\
\hline Dieldrin & & $43(58)$ & Isoprothiolane & & $13(20)$ & & \\
\hline Bromopropylate & & $0(24)$ & Procymidone & & & $55(0)$ & \\
\hline Proclonol & & $3(18)$ & Vinclozoline & & & $91(88)$ & \\
\hline Propaphos & & $25(27)$ & Chlomethoxynil & & $84(56)$ & & \\
\hline Propargite & & $0(37)$ & Diuron & & $0(0)$ & & \\
\hline Tetradifon & & $2(4)$ & Chlornitrofen & $74(16)$ & $99(55)$ & & \\
\hline & & & Simazine & & $17(16)$ & & \\
\hline
\end{tabular}

a) exposure time, ( ): without oleic acid.
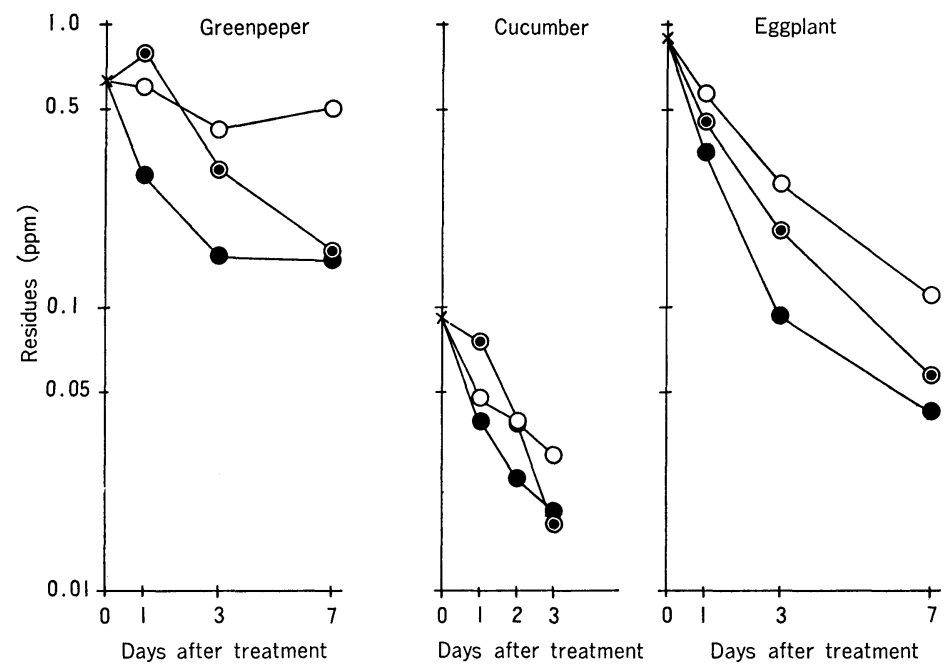

Fig. 8 Effect of oleic acid on photodecomposition of chinomethionat sprayed on vegetable fruits in a green house.

$\bigcirc$ : without treatment of oleic acid, $\odot$ : post-treatment of oleic acid,

- combined treatment of oleic acid.

chinomethionat disappeared, further irradiation with UV light gave rise to little change in the ramining of oleic acid (Fig. 7).

Table 5 shows the effect of oleic acid on photodecomposition of 27 kinds of pesticides. The values in the Table are expressed in the decomposed percentage, compared with the samples kept in the dark. Oleic acid was also effective in the photodecomposition of 7 kinds of pesticides, namely, anilazine, chlomethoxynil, chlornitrofen, chlorothalonil, dichlozoline, dicofol and procymidone. On the other hand, the decomposition of several pesticides such as chlorobenzilate, $o, p^{\prime}$-DDT and bromopropylate was suppressed in the presence of oleic acid. 
The actual effect on chinomethionat photodecomposition by oleic acid was examined on greenpepper, cucumber and eggplant fruits cultivated in a greenhouse. These plants, were treated with oleic acid in the following three ways: without treatment, combined treatment with chinomethionat, and post-treatment after chinomethionat application. As shown in Fig. 8 , treatment of oleic acid resulted in an appreciable decrease in residue of chinomethionat on the plants. From a comparison of effect between combined treatment and post-treatment, it was found that the effect of combined treatment was greater than that of posttreatment.

\section{ACKNOWLEDGEMENTS}

The authors wish to express their sincere thanks to Mr. Masaaki Yamamoto, the chief of Pesticide Residue Laboratory of the Kochi Prefectural Institute of Agricultural and Forest Science, for his valuable suggestion during this study.

\section{REFERENCES}

1) M. Nutahara, M. Yamamoto, T. Murai \& S. Moriya: The Abstract of the Annual Meeting of Pesticide Science Society of Japan, 3rd, p. 127,1978

2) B. L. Glass: J. Agric. Food Chem. 23, 1109 (1975)

3) G. W. Ivie \& J. E. Casida: J. Agric. Food Chem. 19, 405 (1971)

4) C. Botre, A. Mernoli \& F. Alhaique: Environ.
Sci. Technol. 12, 335 (1978)

5) F. S. Tanaka, R. G. Wien \& E. R. Mansagar: $J$. Agric. Food Chem. 27, 774 (1979)

6) G. W. Ivie \& J. E. Casida: J. Agric. Food Chem. 19, 410 (1971)

7) L. Lykken: "Environmental Toxicology of Pesticides,” ed. by F. Matsumura, G. M. Boush \& T. Misato, Academic Press, New York, p. 449, 1972

8) T. Murai, Y. Uesugi, C. Tomizawa \& T. Tanaka: Noyaku Seisan Gijutsu 24, 23 (1971) (in Japanese)

\section{要約}

\section{天然不飽和脂肪酸によるキノメチオナートの光 分解促進効果}

奴田原誠克，村井敏信

キノメチオナートの光分解を保進するナス葉中に含ま れる物質を同定し，その特性について検討した。 光分解 促進物質はオンイン酸等の不飽和脂肪酸で, これらの活 性は不飽和結合に起因し，不飽和脂肪酸部位を有する界 面活性剂，油脂等も同様の活性を示した。二重結合を 1 個有する直鎖不飽和脂肪酸では炭素数が少なくなるほ ど，また不飽和結合がカルボキシル基から離れるほど活 性が大きい傾向を示し，同一脂肪酸では，シス体がトラ ンス体に比べはるかに強い活性を示した。また，他の農 薬に対するオレイン酸の光分解促進効果を検討したとこ ろ, アニラジン,クロメトキシニル，クロルニトロフェ ン, クロロタロニル, ジクロゾリン，ジコホルおよびプ ロシミドンに対しても有効であった。 